\title{
Research Article \\ COMPARATIVE DRYING METHOD STUDY IN DIFFERENT FLOWERS WITH RESPECT TO QUALITY DRY FLOWER PRODUCTS PREPARATION
}

\author{
SINGH DEEPT|* \\ Department of Horticulture (Vegetable and Floriculture), Bihar Agricultural University, Sabour, Bhagalpur, Bihar 813210. \\ *Corresponding Author: Email-singh.deepti2008@gmail.com
}

Received: January 27, 2018; Revised: February 04, 2018; Accepted: February 06, 2018; Published: February 15, 2018

\begin{abstract}
Dry flowers in floriculture sector provide an excellent opportunity in augmenting farmer's income throughout the year despite of the ill hazards of the climatic vagaries faced in open field conditions. Dehydration technology helps in maintaining original colour and shape of flowers for long term utilization with a little care. A wide variation in drying time among different drying method and planting material was recorded. With the sustainable utilization of all family members, farmers can easily generate 1.5 times to 5 times profit by the value addition of dry flowers. For getting higher profits input cost is lowered down by the incorporation of priceless home available waste materials along with dry flower for making floral handicrafts.
\end{abstract}

Keywords- Dehydration, dry flower, eco-friendly.

Citation: Singh Deepti (2018) Comparative Drying Method Study in Different Flowers with Respect to Quality Dry Flower Products Preparation. International Journal of Agriculture Sciences, ISSN: 0975-3710 \& E-ISSN: 0975-9107, Volume 10, Issue 3, pp.-5092-5094. DOl: http://dx.doi.org/10.9735/0975-3710.10.3.5092-5094

Copyright: Copyright@2018 Singh Deepti. This is an open-access article distributed under the terms of the Creative Commons Attribution License, which permits unrestricted use, distribution and reproduction in any medium, provided the original author and source are credited.

Academic Editor / Reviewer: Abhishek Raj, Dr R.G. Khandekar, Dr E.C. Surendranatha Reddy, Dr Brij Lal Attri

\section{Introduction}

Dry flowers have good demand both in Indian and international markets. From India, it is exported to more than 20 countries like USA, Japan and Europe. India stands first in dry flower export owing to the availability of diverse floras. Presently, among all the horticultural produce, Indian floricultural industry is having a more than $70 \%$ share in the export of dry flowers and its value added products. Dry flower market has grown exponentially as consumers are becoming eco-conscious and prefers eco-friendly and biodegradable products of dry flowers alternatively to fresh flowers. There are wide ranges of wild/ unutilized/ underutilized plant species that can be dried from one or the other drying method and can successfully be commercially exploited in different forms $[1,2]$. Dry flower does not mean only flower parts, but also includes dried shoots, seeds, barks, weeds and grasses. Flowers on drying can be easily converted into different valuable products which have a high demand in International market [3]. This is a very easy technology through which women folk or even physically challenged people can also be benefited [4]. This technology is a source of extra income which can overcome farmer's depression during crop failures in field. Export of dried flowers and plants from India is more than Rs 100 Crore per year [5]. Drying flowers at home is an inexpensive and effective way to add a special touch to any decor. It adds value to create decorative centerpieces for home with the benefit of having little maintenance and longer time enjoyment of beautiful flowers. Dried flowers preserve special gift bouquets, creating a beautiful long-lasting arrangement for indoors. Dried flowers are widely used to make handmade paper, lampshades, candle holders, jute bags, photo frames, boxes, books, wall quilts, topiary, cards and several gifts. The use of dry flowers in making of these products enhances the appearance and beauty of these products [6]. Beside this, it also makes us to remember the anniversaries and other related occasions. So, a comparative study of seven drying methods was conducted to find out the best drying method in dry different flowers and plant parts with respect to quality production of value added dry flower products along with determination of benefit cost ratio.

\section{Materials and methods}

The present investigation was conducted at Value Addition Laboratory, Department of Horticulture (Vegetable and Floriculture), Bihar Agricultural University, Sabour during 2014-2017. Seven different types of drying methods (air drying, glycerin drying, hot air oven drying method, microwave drying, press drying, silica gel drying and water drying) were practiced in different flowers, leaves, grasses, weeds and other plant parts and the best drying method was determined along with approximate drying time taken to dry the material in best manner [Table-1]. Among different dry flower, 43 flowers (amaltas, annual chrysanthemum, aster, bottle brush, bougainvillea, candytuft, calendula, chrysanthemum, cineraria, coreopsis, corn flower, cosmos, dahlia, dendrobium, dog flower, gerbera, gaillardia, gomphrena, golden rod, red gulmohar, gypsophila, ixora, larkspur, gladiolus, lotus, lupin, marigold, mussaenda, nasturtium, paper flower, pansy, phlox, poppy, rose, salvia, straw flower, sunflower, sita ashoka, tulip, ursinia, verbena, yellow gulmohar and zinnia) were dried with all the seven drying methods. Different types of 14 ornamental leaves (amhertia, arucaria, bamboo, bottle brush, coreopsis, cosmos, dracaena, fern, Ficus, fish tail palm, lupin, nasturtium, pine and Thuja), along with 04 ornamental grasses (briza, brumus, cuphea grass and doob grass) were also dried with all the seven drying methods. Along with these planting materials, weeds like Ageratum, Sorghum halepense, Phalaris minor, Digeria arvensis, Napier grass, gaji grass, crab grass, Parthenium leaves, Krishna Neel grass, fox tail weed, Oxalis, Eragrostis pilosa, Goose grass and other plant parts like Ocimum inflorescence, candytuft peduncle, tassels of maize, wheat panicles, Coleus inflorescence, bract of Heliconia, Delonix seed cover, Pride of India shoots, Cosmos peduncles were also dried by all the seven drying methods. All the planting material were assessed for the best drying method in terms of colour and form maintenance and out of the best dried method, various types of eco-friendly dry flower products (pen stand, wall quilt, paper weight, photo frames, book mark, coaster and table mat set, cards, birthday caps, dry flower arrangements and sceneries) were made and then on the basis 
dry flower market their benefit cost ratio was estimated [Table-2]. Input cost was calculated by adding the flower cost, raw material cost and labour cost. Then on

Table-1 Best drying method with approx. drying time in different planting material

\begin{tabular}{|c|c|}
\hline Flower/plant part/weeds/grasses & $\begin{array}{l}\text { Best Drying method } \\
\text { (Approx. time taken to dry) }\end{array}$ \\
\hline $\begin{array}{l}\text { Leaves of Lupin, Amhertia and Nasturtium, Fern, Bottle brush, Doob grass, Bambusa, flowers of Lupin, } \\
\text { Nasturtium, Coreopsis, Chrysanthemum, cosmos, Rose, Dendrobium, Cassia, Yellow Gulmohar, Ixora, } \\
\text { Bougainvillea, Red Gulmohar, Verbena, Cineraria, Phlox, Sita ashoka, Golden rod, Cosmos, mussaenda., } \\
\text { Coleus inflorescence, Dendrobium spp., Ursenia, Digeria arvensis, gajri, krishneel grass, oxalis, Goose } \\
\text { grass, Rose, Pansy, poppy. }\end{array}$ & $\begin{array}{l}\text { Press drying at room temperature } 5-6 \text { days (summer)/ } \\
9-10 \text { days (Winter) }\end{array}$ \\
\hline Chrysanthemum leaf, Lupin leaf, Nasturtium leaf, florets of calendula and gerbera. & $\begin{array}{l}\text { Microwave drying at } 50^{\circ} \\
\text { C for } 120 \text { seconds }\end{array}$ \\
\hline Rose, Chrysanthemum, Salvia, Gypsophila, Lupin, Dracaena & Glycerin drying for 10 days \\
\hline Straw flower, Paper flower, Gladiolus. & Water drying for 15 days \\
\hline $\begin{array}{l}\text { Straw flower, Bottle Brush panicle, Brumus, Briza, Cosmos peduncles, Candytuft peduncles, Ocimum } \\
\text { inflorescence, Napier Grass, Heliconia bracts, Wheat panicles, Fox Tail, Thuja, Bottle brush, Arucaria, pine, } \\
\text { Fish Tail palm leaves, Gomphrena, Bougainvillea. }\end{array}$ & $\begin{array}{l}\text { Air drying at } 35-40^{\circ} \mathrm{C} \text { for3- } 4 \text { days (summer) and } 7-8 \text { days } \\
\text { (winter) }\end{array}$ \\
\hline $\begin{array}{l}\text { Candytuft (10 hrs.) } \\
\text { Gulmohar, } \\
\text { Verbena, Larkspur. }\end{array}$ & $\begin{array}{l}\text { Silica Gel Drying ( } 10 \mathrm{hrs} \text { ) at } 45^{\circ} \mathrm{C} \text { in hot air drying. } \\
\text { Silica Gel drying in hot air oven drying }(8 \mathrm{hrs} .) 45^{\circ} \mathrm{C} \text { and } \\
\text { microwave drying ( }(180 \text { seconds }) \text {. }\end{array}$ \\
\hline $\begin{array}{l}\text { Lotus, Larkspur, Gaillardia, Dahlia and Lupin } \\
\text { Gerbera, Chrysanthemum, Dendrobium, Aster, Salvia, Marigold, Zinnia, Calendula, Dog flower Annual } \\
\text { Chrysanthemum } \\
\text { Corn flower, Ursenia, Sunflower }\end{array}$ & $\begin{array}{l}\text { Silica Gel Drying (14 hrs) at } 50^{\circ} \mathrm{C} \text { in Hot air drying } \\
\text { Silica Gel Drying (16 hrs) at } 50^{\circ} \mathrm{C} \text { in Hot air drying } \\
\text { Silica Gel Drying }\left(10 \mathrm{hrs} \text { ) at } 50^{\circ} \mathrm{C} \text { in Hot air drying }\right. \\
\text { Silica Gel Drying (12 hrs) at } 50^{\circ} \mathrm{C} \text { in Hot air drying }\end{array}$ \\
\hline Tulip, Rose, Carnation & $\begin{array}{l}\text { Silica Gel }-20 \text { hrs. in hot air } \\
\text { oven--40 C }\end{array}$ \\
\hline
\end{tabular}

Table-2 Estimated benefit cost ratio of different value added dry flower products

\begin{tabular}{|c|c|c|c|c|c|}
\hline \multirow[t]{2}{*}{ Dry Flower Value Added Products } & \multicolumn{3}{|c|}{ Approximate Input Cost /ndividual Product (Rs.) } & \multirow[t]{2}{*}{ Approximate Rate (Rs.) } & \multirow{2}{*}{$\begin{array}{c}\text { Estimated } \\
\text { Benefit cost ratio }\end{array}$} \\
\hline & $\begin{array}{l}\text { Approx. Manpower } \\
\text { cost (Rs.) }\end{array}$ & $\begin{array}{l}\text { Approx. Time } \\
\text { Spent (minutes) }\end{array}$ & $\begin{array}{l}\text { Approx. cost of raw } \\
\text { material (Rs.) }\end{array}$ & & \\
\hline Pen Stand & 10 & 20 & 05 & 60 & 4.00 \\
\hline Wall Quilt & 20 & 40 & 10 & 60 & 2.00 \\
\hline Paper Weight & 20 & 40 & 80 & 150 & 1.50 \\
\hline Photo Frames & 15 & 30 & 15 & 60 & 2.00 \\
\hline Book Mark & 05 & 10 & 05 & 20 & 2.00 \\
\hline Table Mat (1 pc.) & 15 & 30 & 15 & 60 & 2.00 \\
\hline Coaster Set (6 pcs.) & 20 & 40 & 10 & 60 & 2.00 \\
\hline Sceneries with simple designs $\left(8^{\prime \prime} \times 10^{\prime \prime}\right)$ & 15 & 30 & 150 & 500 & 3.03 \\
\hline Sceneries with fine work $\left(8^{\prime \prime} \times 10^{\prime \prime}\right)$ & 100 & 200 & 300 & 2000 & 5.00 \\
\hline Dry Flower Bouquet/Arrangement & 10 & 20 & 40 & 150 & 3.00 \\
\hline Birthday Cap & 05 & 10 & 05 & 20 & 2.00 \\
\hline Laminated Greeting Card & 10 & 20 & 10 & 60 & 3.00 \\
\hline
\end{tabular}

\section{Results and Discussion}

The results depicted in [Table-1] revealed a wide variation in drying time among different drying method and planting material. The data presented in [Table-1] depicted that different drying methods are specific for different planting material. In summer, usually press drying was completed in 5-6 days whereas with the decline in temperature in winters, the same method with same planting material took 9-10 days to dry. These results of press drying was recorded in the leaves of amhertia, bamboo, bottle brush, doob grass, fern, lupin and nasturtium; flowers of bougainvillea, chrysanthemum, cineraria, coleus, coreopsis, cosmos, cassia, dendrobium, golden rod, lupin, mussaenda., nasturtium, pansy, poppy, rose, yellow gulmohar, ixora, red gulmohar, verbena, phlox, sita ashoka and ursenia; and weeds like Digeria arvensis, gaji , krishneel grass, oxalis and goose grass and the results are in line with the work done by Singh and Kumar [7]. Similarly, air drying gave successful results in straw flower, bottle brush, brumus, briza, cosmos peduncles, candytuft peduncles, ocimum inflorescence, napier Grass, heliconia bracts, wheat panicles, fox tail, thuja, bottle brush panicle, arucaria, pine, fish tail palm leaves, gomphrena, bougainvillea which took 3-4 days drying time in summer season and 7-8 days drying in winter. There was an general observation that planting material with good amount of carbohydrate reserve were properly dried with air drying method and the results matches with the study of Singh, 2015 [8]. Microwave drying at $50{ }^{\circ} \mathrm{C}$ for 120 seconds gave good results in chrysanthemum leaf, lupin leaf, nasturtium leaf, florets of calendula and gerbera, whereas rose, chrysanthemum, salvia, gypsophila, lupin, dracaena were successfully dried by glycerin drying and straw flower, paper flower, gladiolus spikes gave better results with water drying. The results were in line with the work done by Singh [9].

For maintaining flower shape and color, embedded drying with silica gel was practiced in different flowers and there was an general observation that candytuft took approximately 10 hours whereas verbena and larkspur took 8 hours to dry when dried in silica gel in hot air oven at $45^{\circ} \mathrm{C}$ temperature. The same materials when dried in microwave oven then took only 180 seconds at the same temperature. Silica gel drying at a higher temperature of $50^{\circ} \mathrm{C}$ took 14 hours drying time in lotus, larkspur, gaillardia, dahlia and lupin, whereas 16 hours drying time was taken by gerbera, chrysanthemum, dendrobium, aster, salvia, marigold, zinnia, calendula, dog flower whereas corn flower, ursenia, sunflower took only 12 hours to dry at the same condition. Temperate flowers like tulip, carnation and rose required a lower temperature but higher time of 20 hours at $40{ }^{\circ} \mathrm{C}$ to dry. Similar results were founded by Batra [10].

Similarly, [Table-2] displayed the estimated benefit cost ratio of different value added dry flower products like pen stand, wall quilt, paper weight, photo frames, book mark, table mat and coaster set, cards, birthday caps, dry flower arrangements and sceneries of different sizes. The results depicted that minimum time of 10 minutes was spent in making one piece of book mark or birth day cap whereas maximum time of 200 minutes was taken to make 8" x 10"scenery with fine work of dry flower petals pasting. However in terms of raw material consumption the least cost of material consumption was observed in making a book mark, pen stand and birthday cap ( 5 rupees) whereas maximum cost (300 rupees) was consumed in making 8 " x 10 "scenery with fine work. Depending on the national and international demand, the rate of different dry flower products varied from Rs. 15 to Rs. 2000 and similarly the B:C ratio varied from 1.5 to 5.0. 
$\mathrm{B}: \mathrm{C}$ ratio for making paper weight was 1.5 ; for birthday cap, book mark, coaster set, photo frames, table mat and wall quilt $B: C$ ratio was 2.0 , for making simple designed scenery of $8 \times 10$ " size it was 3.03 , for making pen stand it was 4.00 and for making finely designed scenery of $8 \times 10$ " size was 5.0.

\section{Conclusion}

India is endued with diverse range of flora which can easily be dehydrated by simple techniques and converted into high demanding unique ecofriendly products. If produced qualitatively, they can fetch upto 5 times profit then that of the input cost.

\section{Application of Research}

With these findings a diverse range of ecofreindly products can be produced as solely or side business in farmer family which can absorb the financial crisis pressure during crop failures.

\section{Research Category: Dry flowers in floriculture}

Acknowledgement / Funding: Author thankful to Bihar Agricultural University, Sabour, Bhagalpur, Bihar 813210 for funding and support

Principle Investigator: Deepti Singh

University: Bihar Agricultural University, Sabour, Bhagalpur, Bihar 813210

PI, Project: Value Addition of Flowers through Dehydration Technology

Research Group: Product Development and Marketing

Research project name or number: Project No SP/PDM/KH/2015-02

Author Contributions: All author equally contributed

Author statement: All authors read, reviewed, agree and approved the final manuscript

\section{Conflict of Interest: None declared}

Ethical approval: This article does not contain any studies with human participants or animals performed by any of the authors.

\section{References}

[1] Singh D. (2017) Kaushal Vikas Se Krishi Vikas. DEE, BAU, Sabour, 102106.

[2] Bhattacharjee S.K. and L.C. De. (2003) Advanced Commercial Floriculture, 1, 162-173.

[3] Ranjan J.K. and Misra S. (2002) Indian Horticulture, 46, 32-33.

[4] Bhutani J.C. (1995) Advances in Horticulture Ornamental Plants, 12, 10531058.

[5] Singh D. and Kumar S. (2008) Vishwa Krishi Sanchaar, 10,8(2008a),53-54.

[6] Kher M.A. and Bhutani J.C.(1979) Extension Bulletin, NBRI, Lucknow, 120.

[7] Singh D. and Kumar S. (2008) Floriculture Today, 13(1), 42-48.

[8] Singh D. (2015) Floriculture Today, 19(10), 48-50.

[9] Singh D. (2018) Floriculture Today, 22(8), 38-40.

[10] Batra A. (2016) International Journal of Current Research in Bioscience and Plant Biology 3(5), 97-101. 